NASA/TM-2012-217625

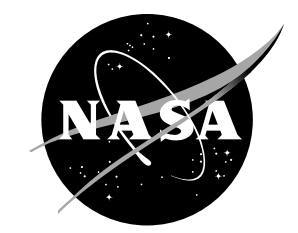

\title{
Ballistic Impact Testing of Aluminum 2024 and Titanium 6Al-4V for Material Model Development
}

J. Michael Pereira, Duane M. Revilock, and Charles R. Ruggeri

Glenn Research Center, Cleveland, Ohio

William C. Emmerling and Donald J. Altobelli

FAA William J. Hughes Technical Center, Atlantic City International Airport, New Jersey 


\section{NASA STI Program . . . in Profile}

Since its founding, NASA has been dedicated to the advancement of aeronautics and space science. The NASA Scientific and Technical Information (STI) program plays a key part in helping NASA maintain this important role.

The NASA STI Program operates under the auspices of the Agency Chief Information Officer. It collects, organizes, provides for archiving, and disseminates NASA's STI. The NASA STI program provides access to the NASA Aeronautics and Space Database and its public interface, the NASA Technical Reports Server, thus providing one of the largest collections of aeronautical and space science STI in the world. Results are published in both non-NASA channels and by NASA in the NASA STI Report Series, which includes the following report types:

- TECHNICAL PUBLICATION. Reports of completed research or a major significant phase of research that present the results of NASA programs and include extensive data or theoretical analysis. Includes compilations of significant scientific and technical data and information deemed to be of continuing reference value. NASA counterpart of peer-reviewed formal professional papers but has less stringent limitations on manuscript length and extent of graphic presentations.

- TECHNICAL MEMORANDUM. Scientific and technical findings that are preliminary or of specialized interest, e.g., quick release reports, working papers, and bibliographies that contain minimal annotation. Does not contain extensive analysis.

- CONTRACTOR REPORT. Scientific and technical findings by NASA-sponsored contractors and grantees.
- CONFERENCE PUBLICATION. Collected papers from scientific and technical conferences, symposia, seminars, or other meetings sponsored or cosponsored by NASA.

- SPECIAL PUBLICATION. Scientific, technical, or historical information from NASA programs, projects, and missions, often concerned with subjects having substantial public interest.

- TECHNICAL TRANSLATION. Englishlanguage translations of foreign scientific and technical material pertinent to NASA's mission.

Specialized services also include creating custom thesauri, building customized databases, organizing and publishing research results.

For more information about the NASA STI program, see the following:

- Access the NASA STI program home page at http://www.sti.nasa.gov

- E-mail your question to help@sti.nasa.gov

- Fax your question to the NASA STI Information Desk at 443-757-5803

- Phone the NASA STI Information Desk at 443-757-5802

- Write to: STI Information Desk NASA Center for AeroSpace Information 7115 Standard Drive Hanover, MD 21076-1320 
NASA/TM-2012-217625

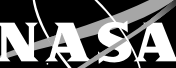

Ballistic Impact Testing of Aluminum 2024 and Titanium 6Al-4V for Material Model Development

J. Michael Pereira, Duane M. Revilock, and Charles R. Ruggeri

Glenn Research Center, Cleveland, Ohio

William C. Emmerling and Donald J. Altobelli

FAA William J. Hughes Technical Center, Atlantic City International Airport, New Jersey

Prepared for the

Earth and Space 2012 Conference

sponsored by the American Society of Civil Engineers

Pasadena, California, April 15-18, 2012

National Aeronautics and

Space Administration

Glenn Research Center

Cleveland, Ohio 44135

July 2012 
This report contains preliminary findings, subject to revision as analysis proceeds.

Trade names and trademarks are used in this report for identification only. Their usage does not constitute an official endorsement, either expressed or implied, by the National Aeronautics and Space Administration.

Level of Review: This material has been technically reviewed by technical management.

Available from

NASA Center for Aerospace Information 7115 Standard Drive

Hanover, MD 21076-1320
National Technical Information Service 5301 Shawnee Road Alexandria, VA 22312

Available electronically at http://www.sti.nasa.gov 


\title{
Ballistic Impact Testing of Aluminum 2024 and Titanium 6Al-4V for Material Model Development
}

\author{
J. Michael Pereira, Duane M. Revilock, and Charles R. Ruggeri \\ National Aeronautics and Space Administration \\ Glenn Research Center \\ Cleveland, Ohio 44135 \\ William C. Emmerling and Donald J. Altobelli \\ FAA William J. Hughes Technical Center \\ Atlantic City International Airport, New Jersey 08405
}

\begin{abstract}
An experimental program is underway to develop a consistent set of material property and impact test data, and failure analysis, for a variety of materials that can be used to develop improved impact failure and deformation models. Unique features of this set of data are that all material property information and impact test results are obtained using identical materials, the test methods and procedures are extensively documented and all of the raw data is available. This report describes ballistic impact testing which has been conducted on aluminum (Al) 2024 and titanium (Ti) 6Al-4vanadium (V) sheet and plate samples of different thicknesses and with different types of projectiles, one a regular cylinder and one with a more complex geometry incorporating features representative of a jet engine fan blade.
\end{abstract}

\section{Introduction}

Numerical simulation of dynamic impact events has reached a level of maturity at which it is commonly used as a design tool for a wide variety of aerospace structures such as jet engine containment systems, fan blades, radomes and cowlings. However, current efforts require extensive testing in parallel with modeling and it is often necessary to adjust model parameters somewhat arbitrarily in order that the model fit the test results. Explicit transient finite element modeling of even the simplest of problems, such as a regularly shaped projectile impacting a flat plate can result in widely varying results, depending on the material and failure models, available material properties, the contact models, the mesh density, and a number of different numerical parameters that must be specified in the computer codes.

One of the difficulties with developing and verifying accurate impact models is that parameters such as high strain rate material properties, failure modes, static properties, and impact test measurements are often obtained from a variety of different sources using different materials, with little control over consistency among the different sources. In addition there is often a lack of quantitative measurements in impact tests to which the models can be compared.

To alleviate some of these problems, a project is underway to develop a consistent set of material property and impact test data, and failure analysis, for a variety of materials that can be used to develop improved impact failure and deformation models. Unique features of this project are that all material property data and impact test data are obtained using identical material, the test methods and procedures are extensively documented and all of the raw data is available. Four parallel efforts are currently underway: Measurement of material deformation and failure response over a wide range of strain rates and temperatures; development of improved numerical modeling techniques for deformation and failure; ballistic impact testing of flat panels and substructures; and failure analysis of material property specimens and impact test articles.

This report focuses on one of these four efforts, the ballistic impact testing for model validation. The report describes impact testing which has been done on aluminum (Al) 2024 and titanium (Ti) 6Al4vanadium (V) sheet and plate samples of different thicknesses and with different types of projectiles, one 
a regular cylinder and one with a more complex geometry incorporating features representative of a jet engine fan blade. Because of the large volume of data produced by this study, not all can be presented here but the methods and major results are given.

\section{Methods}

Impact tests were conducted on flat Al-2024 and Ti-6Al-4V panels with two different areal dimensions, 24 - by 24 -in. (61- by $61-\mathrm{cm}$ ) large panels and 15 - by 15 -in. (38- by $38-\mathrm{cm}$ ) small panels. The smaller panels were impacted in a normal direction with a $0.5 \mathrm{in} .(1.27 \mathrm{~cm})$ diameter cylindrical projectile. The larger panels involved a more complex projectile, with some features representing those of real turbine engine fan blades, impacting the panel in an oblique orientation. Different test setups were used for the two sets of impact tests, as described in the following sections. Strains and displacements were measured on the back side of the panels and post-test metallography was selectively performed to characterize the material microstructure and damage and failure in the test specimens.

\section{Small Panel Test Setup}

Fifteen ballistic impact tests were conducted on each of three different thickness panels of each material. The projectiles were cylindrical with a large radius front face and impacted the plates in a normal orientation. The tests were designed such that the ballistic limit velocity for the particular combinations of projectiles and panels was in the range of 600 to $900 \mathrm{ft} / \mathrm{sec}$ (180 to $275 \mathrm{~m} / \mathrm{sec})$. This corresponds to the speed range of the center of mass of a typical un-contained engine fragment. The impact tests were conducted at speeds above and below the ballistic limit so that some projectiles penetrated and some did not.

Al-2024 sheet and plate, AMS 4037 of three different thicknesses, nominally 0.125, 0.25 and 0.5 in. (3.18, 6.35 and $12.7 \mathrm{~mm}$ ) were tested. The $0.125 \mathrm{in}$. material had a temper of T3 and the 0.25 and $0.5 \mathrm{in}$. material had a temper of T351. The titanium test specimens were annealed Ti-6Al-4V, AMS 4911, with nominal thicknesses of $0.09,0.14$ and 0.25 in. (2.29, 3.56 and $6.35 \mathrm{~mm}$ ).

The test specimens were cut in squares, $15 \mathrm{in} .(38 \mathrm{~cm})$ on a side, with through holes for mounting bolts as shown in Figure 1. The through holes were 9/16 in. $(14.3 \mathrm{~mm})$ diameter on a $13 \mathrm{in} .(33 \mathrm{~cm})$ diameter bolt-hole circle. They were held in a massive steel fixture with a $10 \mathrm{in}$. $(25.4 \mathrm{~cm})$ diameter circular aperture.

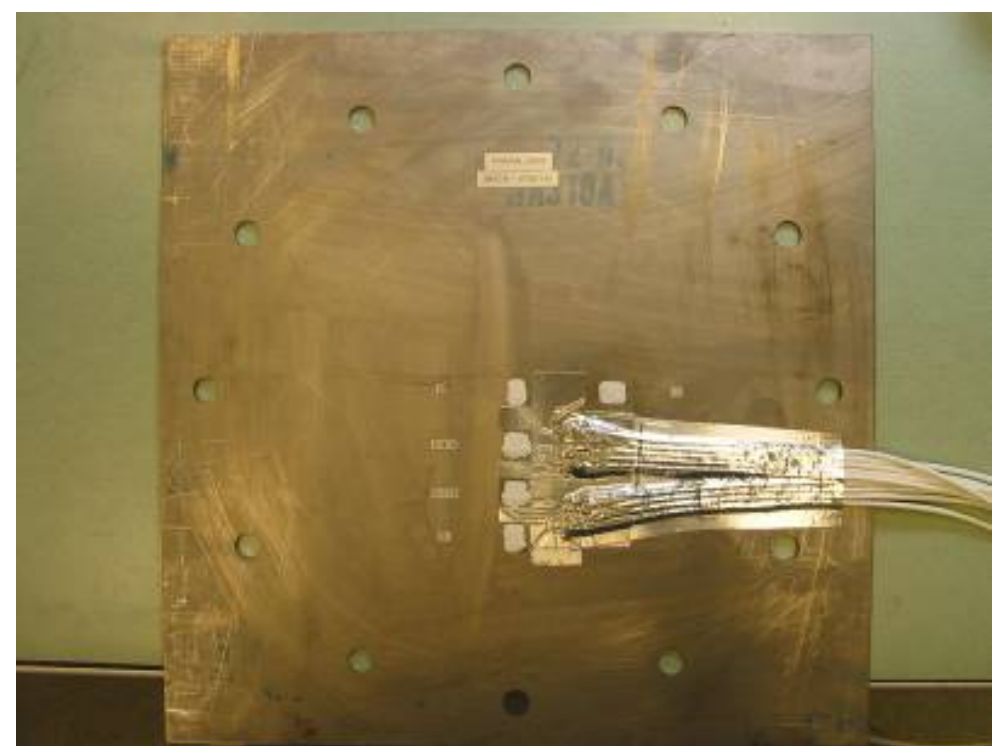

Figure 1.-Plate test specimen with strain gages mounted on the rear face 


\section{Projectiles}

All of the projectiles used for the small panel tests were cylindrical with a diameter of $0.5 \mathrm{in}$. $(12.7 \mathrm{~mm})$ and a relatively large radius of $2.75 \mathrm{in} .(7 \mathrm{~cm})$ on the front face. The nose radius was designed to allow a slight deviation of $5^{\circ}$ in the normal orientation of the projectile. The edge of the front face was "broken" with a 1/32 in. $(0.8 \mathrm{~mm})$ radius. The projectiles were either Ti-6Al-4V or hardened A2 tool steel. The projectiles used for the different test specimens are summarized in Table 1. For the 0.14 in. thick Ti-6Al-4V panels, two different projectiles were used, as shown in the table, to assess the effects of projectile hardness on the penetration velocity. It has been demonstrated in other material systems that the ballistic limit velocity decreases significantly when the projectile hardness exceeds that of the target (Anderson et al., 1999).

TABLE 1.-PROJECTILES USED FOR SMALL PANEL IMPACT TESTS.

\begin{tabular}{|l|l|l|l|c|c|}
\hline Material & $\begin{array}{c}\text { Nominal } \\
\text { thickness, } \\
\text { in. }\end{array}$ & \multicolumn{1}{|c|}{ Projectile material } & $\begin{array}{c}\text { Hardness, } \\
\text { HRC }\end{array}$ & $\begin{array}{c}\text { Length, } \\
\text { in. }\end{array}$ & $\begin{array}{c}\text { Mass, } \\
\text { gram }\end{array}$ \\
\hline Al-2024 & 0.125 & Ti-6Al-4V, AMS 4928 & $36-37$ & 0.7 & 9.0 \\
Al-2024 & 0.25 & Ti-6Al-4V, AMS 4928 & $36-37$ & .9 & 12.8 \\
Al-2024 & 0.5 & A2 Tool Steel & 59 & 1.125 & 28.0 \\
\hline Ti-6Al-4V & 0.09 & Ti-6Al-4V, AMS 4928 & $36-37$ & 1.0 & 14.05 \\
Ti-6Al-4V & 0.14 & Ti-6Al-4V, AMS 4928 & $36-37$ & 1.5 & 21.28 \\
Ti-6Al-4V & 0.14 & A2 Tool Steel* & 59 & .86 & 21.25 \\
Ti-6Al-4V & 0.25 & A2 Tool Steel & 59 & .875 & 21.56 \\
\hline
\end{tabular}

*Used to study the effect of projectile hardness on penetration speed

\section{Gas Gun}

The cylindrical projectiles were accelerated by a helium filled gas gun with a barrel length of $12 \mathrm{ft}$ $(3.7 \mathrm{~m})$, a bore of $2.0 \mathrm{in}$. $(5.08 \mathrm{~cm})$ and a pressure vessel volume of $681 \mathrm{in}^{3}\left(0.011 \mathrm{~m}^{3}\right)$. The projectile was carried down the gun barrel supported by rigid foam in a cylindrical polycarbonate sabot. The gun barrel protruded into a vacuum chamber which held the fixture for the specimens. The sabot was stopped at the end of the gun barrel by a stopper block which had a hole in the front large enough to allow the projectile to pass through. This stopper system was designed such that the bottom of the sabot, including the o-rings, remained in the gun barrel and formed a seal which prevented the gas pressure behind the sabot from affecting the pressure in the vacuum chamber.

\section{Instrumentation}

Data acquired from the impact tests included measurements of the impact velocity, post-impact velocity if penetration occurred, projectile orientation prior to impact, strain gage measurements and fullfield backside strain and displacement measurements using a digital image correlation system. In addition high speed cameras provided qualitative observations of each test.

Seven high speed digital cameras were used for each test. These cameras provided a side view of the front of the panel and two views of the rear of the panel (side and top) for post-impact velocity measurement. In addition, a calibrated pair of cameras located above and in front of the panel were used to measure impact velocity and projectile orientation. A calibrated pair of cameras viewing the backside of the panel were used to compute the backside displacement and strain.

Six of the 15 panels from each of the three thicknesses were instrumented with strain gages. Four of these six instrumented panels had five uniaxial strain gages located as shown in Figure 1. The other two instrumented panels had triaxial rosettes substituted for two of the uniaxial gages, for complete determination of the strain field, resulting in nine strain measurements. Triaxial rosettes allow the determination of the full in plane strain. The uniaxial strain gages were Vishay Micro-Measurements EA- 
06-125AD-120 (Vishay Micro-Measurements, Malvern, PA), with a gage factor of 2.085. The triaxial rosettes were Vishay Micro-Measurements WA-06-060WR-120 with a gage factor of 2.11. The strain gage bridge completion, signal conditioning and recording were performed with a Spectral Dynamics Impax-SD measurement and control system utilizing SD-VX2805 data acquisition modules (Spectral Dynamics, Inc., San Jose, CA). The acquisition rate for the strain gages was $1.25 \mathrm{Msamples} / \mathrm{sec}$.

\section{Projectile Speed and Orientation}

The speed and orientation of the projectile were measured by tracking the position of two points on the projectile and the position of three fixed points which defined the fixed laboratory coordinate system. The point tracking was accomplished with the use of a calibrated pair of high speed cameras (Phantom V7.3, Vision Research, Inc., Wayne, NJ) and the PONTOS point tracking software system (GOM, Braunschweig, Germany). The three fixed points were located on a metal plate mounted to the specimen fixture in a horizontal plane directly below the path of the projectile. The three points defined a coordinate system with the $\mathrm{X}$-axis pointing in the opposite direction of the direction of travel of the projectile, the Zaxis vertically upward and the $\mathrm{Y}$-axis in the horizontal plane and in a direction defined by the vector product of unit vectors in the $\mathrm{Z}$ and $\mathrm{X}$ directions respectively.

The post-impact velocity for the Al panel testing was measured with two high speed cameras on the backside of the panel, oriented normal to the path of the projectile, one viewing from above and one viewing from the left side (viewing from the gun barrel). These cameras were calibrated prior to the impact test using an $\mathrm{Al}$ rod protruding from the gun barrel with calibration marks located at every inch. Calibration tests in which no panel was mounted indicated that the differences in velocity measurements between the two cameras and the PONTOS system were well under 1 percent. For the Ti-6Al-4V panel testing, the orthogonal camera system for exit velocity measurement was replaced with a second pair of calibrated cameras and the PONTOS point tracking system.

\section{Displacement and Strain}

Full-field displacement and strain measurements were obtained using a calibrated pair of high speed digital cameras (Photron model SA1.1, Photron USA, San Diego, CA) and a digital image correlation software package (ARAMIS, GOM, Braunschweig, Germany). The cameras were located on the outside of the vacuum chamber and viewed the backside of the panel through two viewports. The distance from the cameras to the panel was approximately 36 in. $(0.9 \mathrm{~m})$ and the distance between the cameras was approximately 16 in. Initially the cameras recorded an area of approximately 4 - by 4 in. (10- by 10-cm) with a resolution of 128 pix in the horizontal direction and 128 pix in the vertical direction and a frame rate of 180,000 frames/sec. Later tests used a resolution of $128 \times 160$ pixels and a frame rate of 150,000 frames/sec. The back side of each panel was painted with a random set of black dots on a white background as required by the ARAMIS software. From the images, the software computed the displacements in three directions at any point in the view for every recorded frame. In-plane strains on the back surface of the panel were computed from the displacements.

\section{Large Panel Test Setup}

Four ballistic impact tests were conducted on larger flat panels of each material. These tests were designed to involve a more realistic projectile and non-normal impact orientation to provide data for validation of numerical models under conditions more complex than the small panel tests.

\section{Test Specimens}

The Al test specimens were 24- by 24-in. (61- by 61-cm) Al-2024-T351 with a nominal thickness of 0.25 in. (6.35 mm). The titanium test specimens were 24 - by 24 -in. (61- by $61-\mathrm{cm}$ ) annealed Ti-6Al-4V, AMS 4911, with a nominal thickness of 0.090 in. $(2.29 \mathrm{~mm})$. The panels were held at a $45^{\circ}$ angle in a square fixture 
with a 20 - by 20 -in. (50.8- by $50.8 \mathrm{~cm}$ ) aperture as shown in Figure 2. The panels were through-bolted with 24 $0.5 \mathrm{in}$. $(12.7 \mathrm{~mm})$ bolts equally spaced around the sides, 1.0 in. $(2.54 \mathrm{~cm})$ in from the edges.

The projectile used for the large panel test was designed to include some of the features of a real fan blade, such as a thin tip and a heavier shank, while being relatively simple to manufacture and model. It was made from annealed Ti-6Al-4V, AMS 4911 and had a nominal mass of 340 gram. The dimensions are shown in Figure 3. The projectile impacted the panel at a nominal angle of $-45^{\circ}$ as shown in Figure 2 .

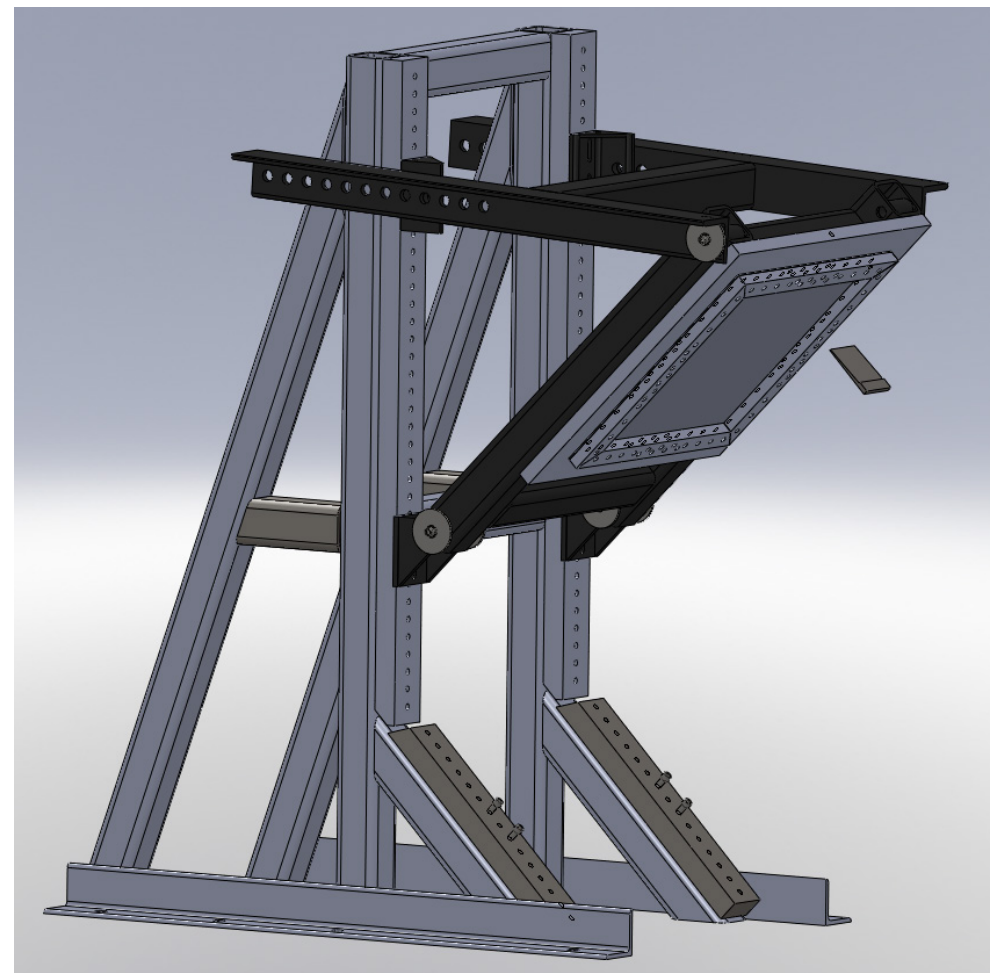

Figure 2.-Schematic of the large panel test setup showing the orientation of the projectile and test specimen
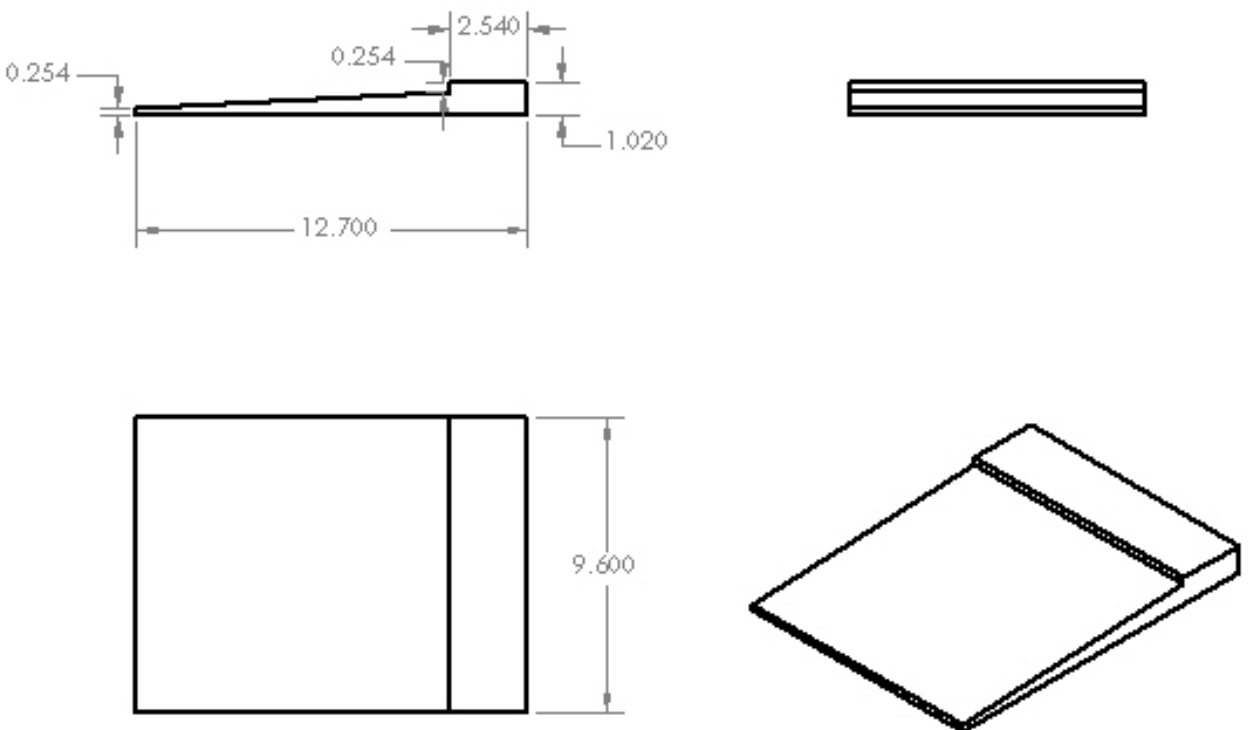

Figure 3.-Dimensions of the projectile used in the large panel impact tests. Dimensions in centimeters. 


\section{Results and Discussion}

\section{Small Panel Impact Tests}

The penetration velocity for each combination of panel and projectile was derived by plotting the projectile residual velocity against the impact velocity. Sample results are shown in Figure 4 and Figure 5 for $\mathrm{Al}$ and Ti panels. The penetration velocities derived from these curves are shown in Table 2 .

TABLE 2.-APPROXIMATE PENETRATION VELOCITY FOR THE SMALL PANEL IMPACT TESTS

\begin{tabular}{|l|l|l|c|c|c|c|}
\hline & $\begin{array}{c}\text { Measured } \\
\text { thickness, } \\
\text { in. }\end{array}$ & Projectile material & $\begin{array}{c}\text { Hardness, } \\
\text { HRC }\end{array}$ & $\begin{array}{c}\text { Length, } \\
\text { in. }\end{array}$ & $\begin{array}{c}\text { Mass, } \\
\text { gram }\end{array}$ & $\begin{array}{c}\text { Penetration } \\
\text { velocity, } \\
\text { ft/sec }\end{array}$ \\
\hline Al-2024 & 0.126 & Ti-6Al-4V & $36-37$ & 0.7 & 9.0 & 700 \\
Al-2024 & 0.255 & Ti-6Al-4V & $36-37$ & .9 & 12.8 & 750 \\
Al-2024 & 0.503 & A2 Tool Steel & 59 & 1.125 & 28.0 & 800 \\
\hline Ti-6Al-4V & 0.092 & Ti-6Al-4V & $36-37$ & 1.0 & 14.05 & 740 \\
Ti-6Al-4V & 0.135 & Ti-6Al-4V & $36-37$ & 1.5 & 21.28 & 770 \\
Ti-6Al-4V & 0.135 & A2 Tool Steel* & 59 & .86 & 21.25 & 650 \\
Ti-6Al-4V & 0.254 & A2 Tool Steel & 59 & .875 & 21.56 & 735 \\
\hline
\end{tabular}

* Used to study the effects of projectile hardness

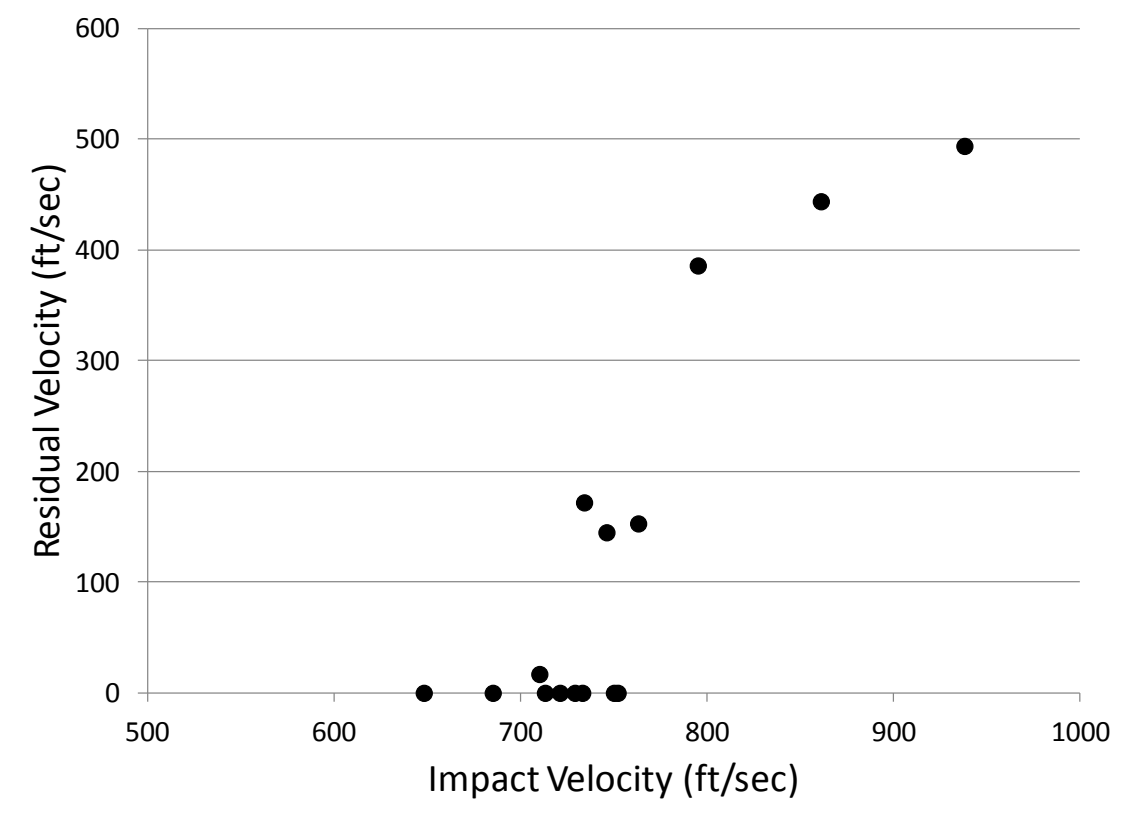

Figure 4.- Residual velocity as a function of impact velocity for the $0.25 \mathrm{in}$.

$(6.4 \mathrm{~mm})$ thick Al-2024 small panels. 


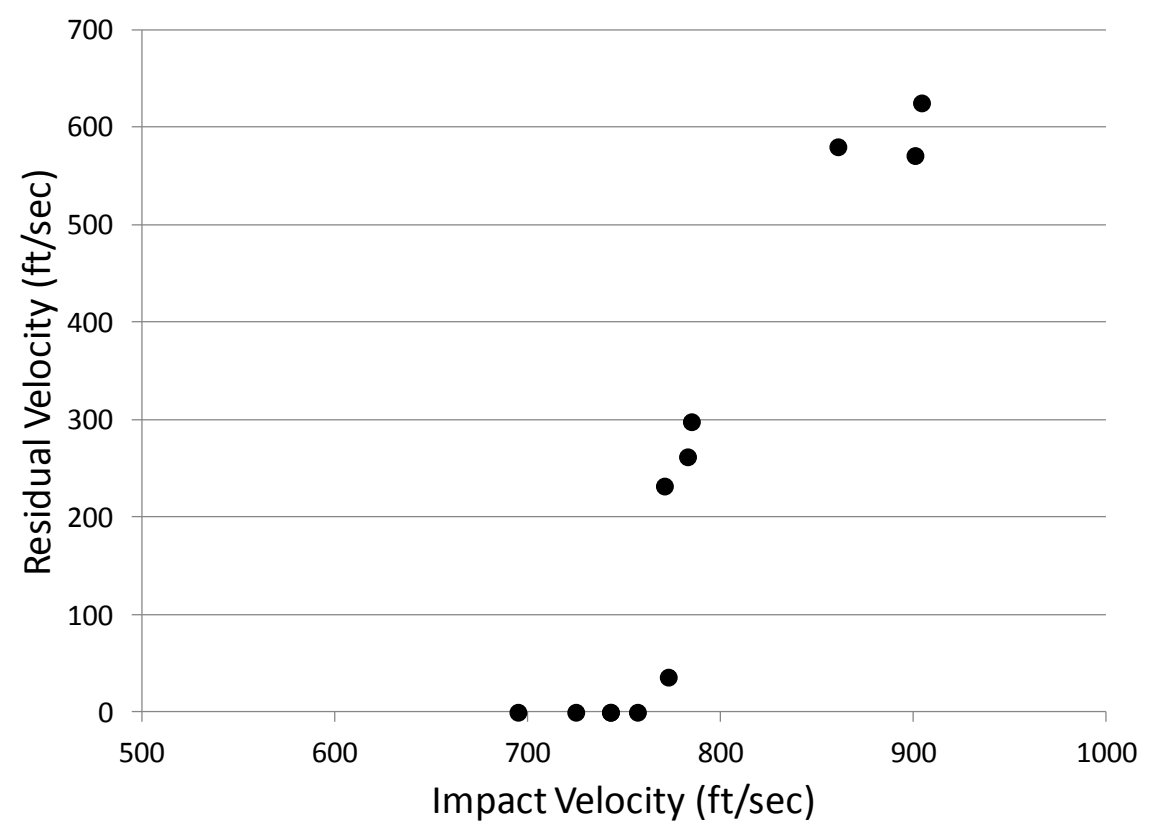

Figure 5.-Residual velocity as a function of impact velocity for the $0.14 \mathrm{in}$. (3.6 mm) thick Al-2024 small panels.

The residual velocity curves for the $0.125 \mathrm{in}$. (3.18 mm) and the $0.25 \mathrm{in}$. (6.35 mm) Al-2024 plates has a fairly well defined transition between penetration and non-penetration, and a generally regular increase in residual velocity as the impact velocity increases. However, for the 0.5 in. (12.7 mm) thick Al2024 plates there is a considerable range of impact velocities where in some cases penetration occurred and in others it did not. It is not clear why this occurred for the thick plates. One speculation is that friction plays a more important role in the thicker plates. It is also possible that there is some interaction from waves reflecting from the boundaries of the plate. For the heavier and longer projectiles used for the 0.5 in thick plates the projectile orientation was generally very good, so the impact angle could not be considered an explanation for the irregularities.

For all of the Ti-6Al-4V tests there was a well-defined transition between tests where penetration occurred and those where there was no penetration as well as a generally regular increase in residual velocity as the impact velocity increased.

\section{Strain Measurements}

Strain measurements on the backside of the panels were recorded using both strain gages and the digital image correlation (DIC) system. Because of the large volume of strain data collected in this study, not all results can be reported here, but a number of observations can be made. In all cases the strain gage located on at the center of the panel failed immediately upon impact but in general data was available from the rest of the gages.

With current camera technology there is a compromise between video acquisition speed and spatial resolution which can potentially limit the accuracy of strain calculations based on DIC deflection measurements. Filtering parameters used in computing strains can affect the values, particularly when there are high strain gradients and limited spatial resolution. The use of strain gages allows the DIC computed strains to be verified, and ensures that the optimum filtering parameters are used. A number of comparisons were made to check the correlation between strain measurements using the two measurement methods. In making the comparisons it was questionable whether using the DIC system to 
measure the strain at the actual location of the gage would give accurate results, due to the coating used and the existence of the gage itself. So in addition to comparing the results at the gage location, the strain gage results were also compared with DIC results at the same radial distance from the impact point, but at a location $180^{\circ}$ away. Due to the symmetry of the impact configuration, the radial strains should be equal at equal distances from the center.

Figure 6 shows a strain gage measurement compared with two DIC strain measurements, one directly on the gage and the other at a location $180^{\circ}$ away from the strain gage. These measurements were on a 0.125 in. $(3.18 \mathrm{~mm})$ thick Al-2024 panel impacted at $733 \mathrm{ft} / \mathrm{sec}(223 \mathrm{~m} / \mathrm{sec})$. There is good agreement between all three measurements.

\section{Large Panel Impact Tests}

Four impact tests were conducted on each of the large Al-2024 and Ti-6Al-4V panels described above, using the blade-simulating projectile. Results of these tests are shown in Table 3(a) and (b). The tests bound the range of penetrated and non-penetrated for both materials, providing data useful for validating computational models.

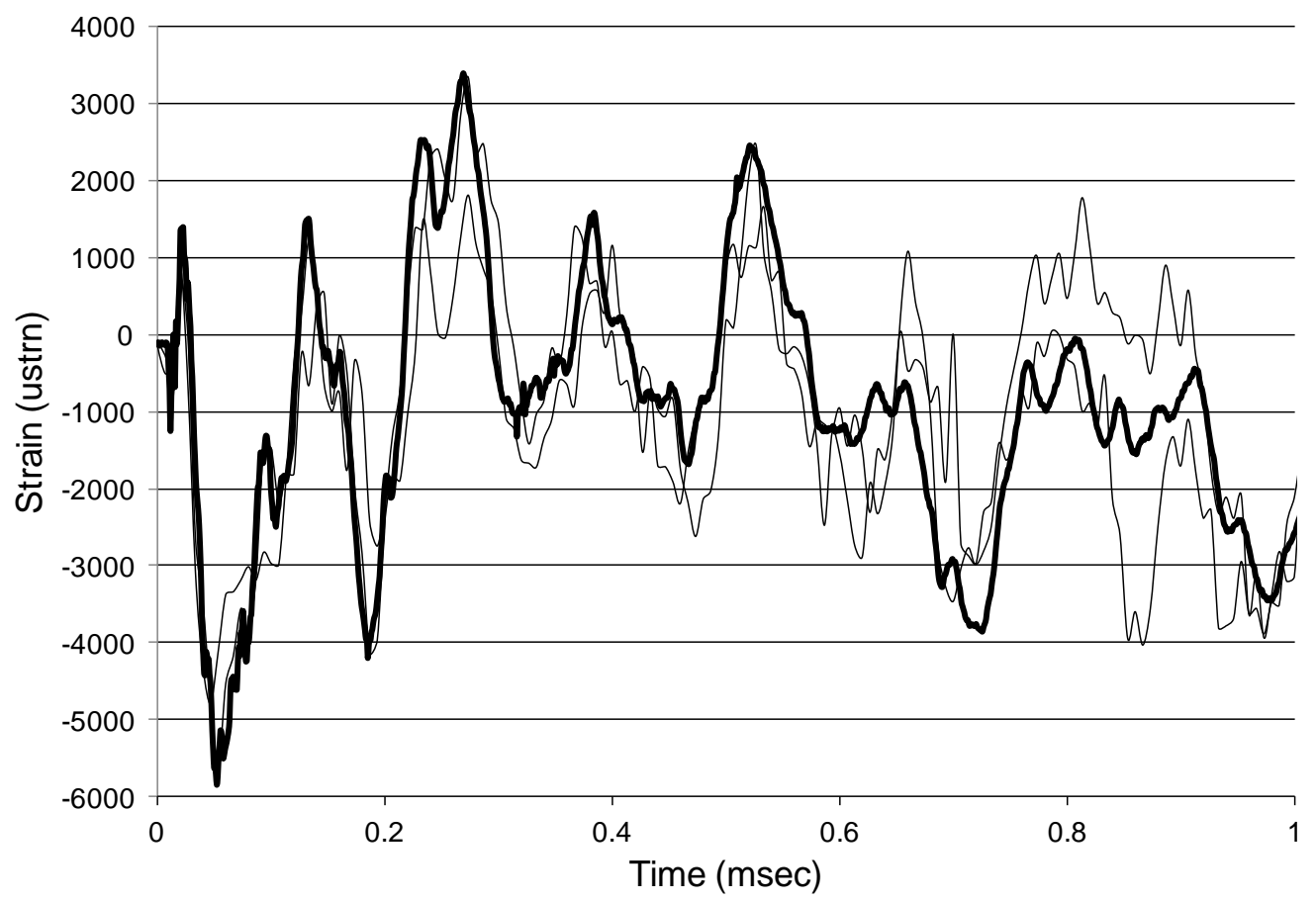

Figure 6.-Comparison of strain gage (bold line) and DIC strain measurements on a 0.125 in. thick Al-2024 panel impacted at $733 \mathrm{ft} / \mathrm{sec}(223 \mathrm{~m} / \mathrm{sec})$. 
TABLE 3.-RESULTS OF IMPACT TESTS ON LARGE AL2024 AND TI-6AL-4V PANELS

(a) Results of impact tests on large Al2024 panels

\begin{tabular}{|c|c|c|c|c|l|}
\hline $\begin{array}{c}\text { Test } \\
\text { ID }\end{array}$ & $\begin{array}{c}\text { Measured } \\
\text { thickness, } \\
\text { in. }\end{array}$ & $\begin{array}{c}\text { Projectile } \\
\text { material }\end{array}$ & $\begin{array}{c}\text { Projectile } \\
\text { mass, } \\
\text { gram }\end{array}$ & $\begin{array}{c}\text { Impact } \\
\text { velocity, } \\
\mathrm{ft} / \mathrm{sec}\end{array}$ & \multicolumn{1}{|c|}{ Result } \\
\hline LG908 & 0.257 & Ti-6Al-4V & 330 & 691 & Contained. \\
LG909 & .259 & Ti-6Al-4V & 338 & 791 & Contained, perforated \\
LG910 & .257 & Ti-6Al-4V & 329 & 743 & Contained, perforated \\
LG911 & .257 & Ti-6Al-4V & 338 & 706 & Contained, perforated \\
\hline
\end{tabular}

(b) Results of impact tests on large Ti-6Al-4V panels

\begin{tabular}{|c|c|c|c|c|l|}
\hline $\begin{array}{c}\text { Test } \\
\text { ID }\end{array}$ & $\begin{array}{c}\text { Measured } \\
\text { thickness, } \\
\text { in. }\end{array}$ & $\begin{array}{c}\text { Projectile } \\
\text { material }\end{array}$ & $\begin{array}{c}\text { Projectile } \\
\text { mass, } \\
\text { gram }\end{array}$ & $\begin{array}{c}\text { Impact } \\
\text { velocity, } \\
\text { ft/sec }\end{array}$ & Result \\
\hline LG908 & 0.094 & Ti-6Al-4V & 339 & 618 & Contained. Small crack \\
LG909 & .095 & Ti-6Al-4V & 344 & 698 & Projectile penetrated \\
LG910 & .094 & Ti-6Al-4V & 344 & 645 & Projectile penetrated \\
LG911 & .094 & Ti-6Al-4V & 344 & 575 & Contained. No cracks \\
\hline
\end{tabular}

\section{Summary}

This report provides results of instrumented impact tests on 15 in. square Al-2024 and Ti-6Al-4V panels of three different thicknesses impacted in a normal direction by a cylindrical projectile and 24 in. square panels of the same materials impacted at a $45^{\circ}$ angle by a more complex projectile having blade-like features. The experimental program was designed such that the penetration velocity was in the range of 600 to $900 \mathrm{ft} / \mathrm{sec}$ (180 to $275 \mathrm{~m} / \mathrm{sec}$ ). This was accomplished by varying the mass of the projectile, either through length or material changes, while keeping the projectile front face geometry and diameter constant (in the case of the small panel tests), or selecting the thickness of the material to achieve this speed range (in the case of the large panel tests). In the small panel tests the transition between penetration and nonpenetration was well defined, except in the case of the thickest material studied, the 0.5 in. thick Al-2024. In this case there was a significant velocity range over which both penetration and non-penetration occurred. The reasons for this are not known, but it is speculated that friction may play a role.

Strain measurements in the small panel tests, using both strain gages and a digital image correlation system, indicated that there is good agreement between the two. In addition it was shown that strain measurements at different circumferential locations, but identical radial distances from the impact point showed excellent correlation, as would be expected. The large panel tests provide an excellent means of validating computational models in a more complex test configuration than the small panel tests.

Extensive material characterization of the same materials, over a wide range of strain rates and temperatures are provided in a set of separate reports currently under preparation. Unique features of the data provided include extensive documentation of test procedures and results, material characterization of the very same materials used for impact testing, and extensive instrumentation results. These reports provide a valuable set of data which can be used for developing and validating computational high strain rate and impact deformation and failure models. Although it is impossible to report all data in a single report, it is archived and available through the authors.

\section{References}

Anderson, C.E., Jr., Hohler, V. and Walker, J.D. (1999) "The influence of projectile hardness on ballistic performance,” International Journal of Impact Engineering, 22 (6) 22, p. 619-632. 


\begin{tabular}{|c|c|c|c|c|c|}
\hline \multicolumn{5}{|c|}{ REPORT DOCUMENTATION PAGE } & $\begin{array}{l}\text { Form Approved } \\
\text { OMB No. 0704-0188 }\end{array}$ \\
\hline \multicolumn{6}{|c|}{$\begin{array}{l}\text { The public reporting burden for this collection of information is estimated to average } 1 \text { hour per response, including the time for reviewing instructions, searching existing data sources, gathering and maintaining the } \\
\text { data needed, and completing and reviewing the collection of information. Send comments regarding this burden estimate or any other aspect of this collection of information, including suggestions for reducing this } \\
\text { burden, to Department of Defense, Washington Headquarters services, Directorate for Information Operations and Reports (0704-0188), 1215 Jefferson Davis Highway, Suite } 1204 \text {, Arlington, VA } 22202-4302 \text {. } \\
\text { Respondents should be aware that notwithstanding any other provision of law, no person shall be subject to any penalty for failing to comply with a collection of information if it does not display a currently valid OMB } \\
\text { control number. } \\
\text { PLEASE DO NOT RETURN YOUR FORM TO THE ABOVE ADDRESS. }\end{array}$} \\
\hline \multicolumn{2}{|c|}{$\begin{array}{l}\text { 1. REPORT DATE (DD-MM-YYYY) } \\
07-01-2012\end{array}$} & \multicolumn{3}{|c|}{$\begin{array}{l}\text { 2. REPORT TYPE } \\
\text { Technical Memorandum }\end{array}$} & 3. DATES COVERED (From - To) \\
\hline \multirow{3}{*}{\multicolumn{5}{|c|}{$\begin{array}{l}\text { 4. TITLE AND SUBTITLE } \\
\text { Ballistic Impact Testing of Aluminum } 2024 \text { and Titanium 6Al-4V for Material Model } \\
\text { Development }\end{array}$}} & 5a. CONTRACT NUMBER \\
\hline & & & & & 5b. GRANT NUMBER \\
\hline & & & & & 5c. PROGRAM ELEMENT NUMBER \\
\hline \multirow{3}{*}{\multicolumn{5}{|c|}{$\begin{array}{l}\text { 6. AUTHOR(S) } \\
\text { Pereira, J., Michael; Revilock, Duane, M.; Ruggeri, Charles, R.; Emmerling, William, C.; } \\
\text { Altobelli, Donald, J. }\end{array}$}} & 5d. PROJECT NUMBER \\
\hline & & & & & 5e. TASK NUMBER \\
\hline & & & & & $\begin{array}{l}\text { 5f. WORK UNIT NUMBER } \\
\text { WBS 284848.02.04.03.03.03.02 }\end{array}$ \\
\hline \multicolumn{5}{|c|}{$\begin{array}{l}\text { 7. PERFORMING ORGANIZATION NAME(S) AND ADDRESS(ES) } \\
\text { National Aeronautics and Space Administration } \\
\text { John H. Glenn Research Center at Lewis Field } \\
\text { Cleveland, Ohio 44135-3191 }\end{array}$} & $\begin{array}{l}\text { 8. PERFORMING ORGANIZATION } \\
\text { REPORT NUMBER } \\
\text { E-18213 }\end{array}$ \\
\hline \multirow{2}{*}{\multicolumn{5}{|c|}{$\begin{array}{l}\text { 9. SPONSORING/MONITORING AGENCY NAME(S) AND ADDRESS(ES) } \\
\text { National Aeronautics and Space Administration } \\
\text { Washington, DC 20546-0001 }\end{array}$}} & $\begin{array}{l}\text { 10. SPONSORING/MONITOR'S } \\
\text { ACRONYM(S) } \\
\text { NASA }\end{array}$ \\
\hline & & & & & $\begin{array}{l}\text { 11. SPONSORING/MONITORING } \\
\text { REPORT NUMBER } \\
\text { NASA/TM-2012-217625 }\end{array}$ \\
\hline \multicolumn{6}{|c|}{$\begin{array}{l}\text { 12. DISTRIBUTION/AVAILABILITY STATEMENT } \\
\text { Unclassified-Unlimited } \\
\text { Subject Categories: } 01 \text { and } 37 \\
\text { Available electronically at http://www.sti.nasa.gov } \\
\text { This publication is available from the NASA Center for AeroSpace Information, 443-757-5802 }\end{array}$} \\
\hline \multicolumn{6}{|c|}{ 13. SUPPLEMENTARY NOTES } \\
\hline \multicolumn{6}{|c|}{$\begin{array}{l}\text { 14. ABSTRACT } \\
\text { An experimental program is underway to develop a consistent set of material property and impact test data, and failure analysis, for a variety } \\
\text { of materials that can be used to develop improved impact failure and deformation models. Unique features of this set of data are that all } \\
\text { material property information and impact test results are obtained using identical materials, the test methods and procedures are extensively } \\
\text { documented and all of the raw data is available. This report describes ballistic impact testing which has been conducted on aluminum (Al) } \\
2024 \text { and titanium (Ti) 6Al-4vanadium (V) sheet and plate samples of different thicknesses and with different types of projectiles, one a } \\
\text { regular cylinder and one with a more complex geometry incorporating features representative of a jet engine fan blade. }\end{array}$} \\
\hline \multicolumn{6}{|c|}{$\begin{array}{l}\text { 15. SUBJECT TERMS } \\
\text { Mechanical properties; Ballistic impact }\end{array}$} \\
\hline \multicolumn{3}{|c|}{ 16. SECURITY CLASSIFICATION OF: } & $\begin{array}{l}\text { 17. LIMITATION OF } \\
\text { ABSTRACT }\end{array}$ & $\begin{array}{l}\text { 18. NUMBER } \\
\text { OF }\end{array}$ & $\begin{array}{l}\text { 19a. NAME OF RESPONSIBLE PERSON } \\
\text { STI Help Desk (email:help@sti.nasa.gov) }\end{array}$ \\
\hline $\begin{array}{l}\text { a. REPORT } \\
\text { U }\end{array}$ & $\begin{array}{l}\text { b. ABSTRACT } \\
\text { U }\end{array}$ & $\begin{array}{l}\text { c. THIS } \\
\text { PAGE } \\
\text { U }\end{array}$ & UU & $\begin{array}{c}\text { PAGES } \\
16\end{array}$ & $\begin{array}{l}\text { 19b. TELEPHONE NUMBER (include area code) } \\
443-757-5802\end{array}$ \\
\hline
\end{tabular}



